\title{
Form FDA 1572
}

National Cancer Institute

\section{Source}

National Cancer Institute. Form FDA 1572. NCI Thesaurus. Code C54623.

A federal form that is the statement of the investig ator that he will abide by the federal guidelines set forth in the Code of Federal Regulations for the use of drugs in an investigational setting. 